\title{
The technical and the social: challenges in the conservation of earthen vernacular architecture in a changing world (Jujuy, Argentina)
}

\author{
Jorge Tomasi ${ }^{*}$ (i) and Julieta Barada
}

\begin{abstract}
Vernacular earthen architecture presents a series of relevant conservation challenges that involve designing solutions for different kinds of alterations and degradations. Other challenges of a social nature simultaneously arise and are related, among other factors, to the participation of local communities and the actions of different institutional actors. Understanding these phenomena has generally been approached from perspectives that take technical considerations and social dynamics as separate fields. The current global context has resulted in an acceleration of changes in these dynamics, in terms of both techniques and management models, giving rise to the need to develop comprehensive conceptual and methodological approaches through which these challenges should be addressed jointly by recombining the technical and the social.

This paper will analyse the main problems affecting vernacular architectures in three communities in northern Argentina, where earthen techniques have been very relevant. We will reflect on various potentially useful theoretical frameworks, incorporating concepts from the anthropology of technology and methodological approaches from an ethnography of conservation as a way to work with multiple ontologies.
\end{abstract}

Keywords: Heritage ethnography, Vernacular architecture, Anthropology of techniques

\section{Introduction}

The meanings and social representations associated with the technical in construction and in other fields have been part of the disciplinary debates in anthropology since the beginning of the 20th century; these debates have centred around the understanding of the technical as a social fact (Lemonnier 1992; Dietler and Herbich 1998). This has allowed a perspective to emerge that questions the objectivity of the technical in order to recognise how technical choices are affected by diverse subjectivities that are

\footnotetext{
*Correspondence: jorgetomasi@hotmail.com

CONICET - Laboratorio de Arquitecturas Andinas y Construcción con Tierra, Instituto de Investigaciones sobre la Naturaleza y la Cultura "Rodolfo Kusch", Universidad Nacional de Jujuy, Rivadavia 642, Tilcara, Provincia de Jujuy, Argentina
}

socially modelled over time. Indeed, every material fact, and the technological decisions relating to its production and maintenance, are immersed in complex networks of diverse actors marked by asymmetrical power relations within changing contexts.

Certainly, this view of the technical as a social fact is relevant for thinking about architectural conservation, and recent theoretical debates have featured such questions. Within the framework of these debates, it is possible to recognise two fields of discussion relevant to this article. On the one hand is cultural and social significance, and its corresponding diversity, in the determination of heritage value (Bluestone 2000), and on the other hand are the criteria for the intervention to be applied, as expressed first in the Burra Charter (1975) and, more 
recently, in the Nara Charter (1994) centred on the concept of authenticity (Correia 2007).

Any problematisation of cultural significance necessarily involves looking at the various temporalities associated with architecture and its durability and thus how the concept of change is analysed (Jones and Yarrow 2013). This is a particularly important issue for earthen heritage in relation to the durability of this material and the need for periodic intervention to ensure its proper maintenance (Correia 2007; Tomasi and Barada 2020).

The second and related field of discussion has been very relevant in the last decade; it refers to the participation of local actors in defining both heritage itself and the criteria for related interventions (Johnston and Myers 2009; Alonso González 2015; Watkins 2019). The observation of other actors' ontologies, more than simply various points of view, necessarily implies a recognition of the social networks in which they are employed, complex power relations operate, and social representations of technology are established (Lemonnier 1992). As Alonso González stated, heritage "emerges from social relationality" (2015: 183) with differential appropriations and constructions. This implies that there are discussions of the institutionalised idea of heritage as an object or a place that concentrates certain essential values to be preserved or to considering it, in the words of Smith (2011), as a cultural process in which memories, identities and senses of belonging are negotiated. These negotiations operate between actors who are embedded in asymmetrical power relations, so it is necessary to consider the interaction contexts in which they operate (Alonso González 2015). It also implies a reflection on the place occupied by professionals who work with communities to conserve their heritage, on our institutional belonging and on which criteria we use and often naturalise. These approaches and critical heritage studies have contributed to the discussion of the concept, the complexification of heritage processes, the development of methodologies for incorporating other ontologies, and the establishment of alternative management models. However, beyond strictly technical studies, the technological universe related to architectural conservation efforts has not been specifically considered as an integral part of heritage discussions. This leads to a certain fragmentation of the research, stranding the technical in a plane of objectivities, and not as a field of dispute regarding heritage narratives in and of itself.

Considerations of the temporalities of architectural heritage, technical choices for its conservation, and the participation of multiple actors within the network of relationships require incorporating theoretical and methodological tools for the social understanding of these processes. Anthropological approaches to technique and ethnographic perspectives offer the possibility of deepening analyses of the social condition of technological choices within conservation by observing the way in which these aspects emerge from relationships between diverse actors, including those with different local points of view. In this way, it is possible to reflect on the temporality of architecture as a general framework for conservation practices, problematizing the meaning of change as an inherent social fact. This allows us to question the place that change has had in conservation theory in occidental terms through the meanings that it can assume from the conceptions of local communities.

In this paper, we analyse earthen heritage conservation through three case studies of emblematic architectures in Uquía, Yavi and Tabladitas in northern Argentina (Fig. 1). This will allow us to observe the technical and then social dimensions linked to the conservation of these architectures through the interactions between different actors and recognise the emerging material implications of these relationships. At the same time, looking at these architectures over time will allow us to analyse the processes of change by discussing the meaning of their transformations in terms of both local and institutional actors and their own temporalities. Ultimately, we seek to reassemble the understanding of technical actions with their diverse social representations in the terms in which they are deployed in these three case studies.

References to local and institutional actors do not imply the consolidation of antagonism or the existence of completely independent or autonomous social collectives. In contrast, throughout the text, multiple interactions and changes in their relative positions will be observed. The construction of institutionality includes state agencies and international organisations, among other actors, which constitute a heterogeneous group with diverse and even contradictory interests that have historically shaped relationships with the various surrounding communities. These groups frequently also participate in institutionalised discourses and actions, while in the same or other contexts, they deploy a universe of tactics to resist, appropriate or manipulate the actions of the states. In this way, the work carried out in the Church of Uquía allows us to observe the technical problems emerging from the changes in materiality resulting from the action of state institutions during the 20th century. The Church of Tabladitas reveals the dynamics of change within the local community itself in the context of the regular conservation practices for the building. Finally, Casa del Marques, in the town of Yavi, helps us analyse the intersections between local communities and state agencies in the social representation of roofing techniques within the framework of the various interventions that have been carried out in the building. In this way, these three cases, 


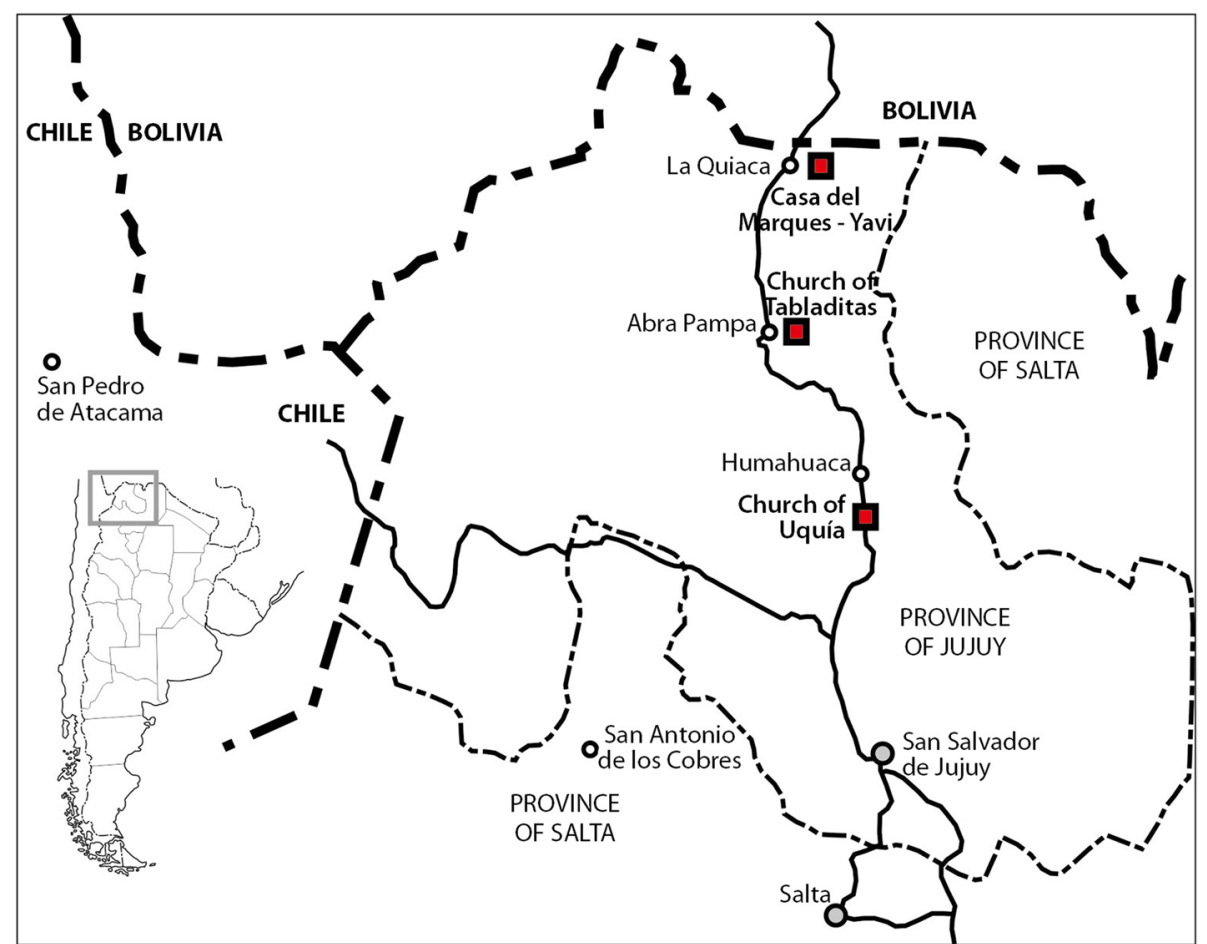

Fig. 1 Location of the three case studies in the province of Jujuy, Argentina (Source: the authors)

which will be described technically and socially, allow us to think about change according to different social contexts and the different action patterns of the actors involved.

In methodological terms, the material used in this article emerges from research that was carried out during architectural intervention projects, involved collaborative work with various local and institutional actors, and took a general ethnographic approach. In the cases of Uquía and Yavi, our participation arose from a request to a provincial state institution responsible for architectural conservation that the diagnostic and intervention work should involve local communities. In the case of Tabladitas, on the other hand, our participation emerged from a request from the community itself, given the observable damages in its church. Thus, we were not external observers; we come from the academic field and we are part of that relational constitution of heritage, in the words of Alonso González (2015). This type of work requires considering one's own position in the field in relation to an ethnographic reflexivity emerging from relationships between different social subjects, including ourselves, that are no longer separate. The fieldwork involved techniques such as participant observation and the development of a set of participatory workshops with different local and institutional actors as a way to implement diagnoses and projects assuming a multiplicity of ontologies along with their assemblages, tensions and points of contact. Using this approach, the set of technical decisions made by the different actors about the buildings can be integrated into their trajectories and intersections. This article, then, is not oriented around the analysis of the state's impositions on the communities but rather around understanding the way that the technical emerges from the complex relationships among the actors.

\section{Anthropologies of technology and ethnographies for conservation}

In the course of the conceptual discussions within conservation theory, certain universal principles have begun to be relativised through the incorporation of ideas regarding the diversity of cultural meanings (Correia 2007). These debates, at least in doctrinal texts, imply a revision of the culturally and socially defined temporalities of architecture as well as its duration and change as an inherent fact of its existence. The meanings historically associated with the development of architecture are inseparable from the set of practices and techniques related to its conservation in different social and cultural contexts. This leads to questions about the status of techniques as social facts, the reasons that motivate technological choices, and the possible approaches to the analysis of these other possible conceptions of conservation. As Dietler and Herbich proposed, "both things and 
techniques are embedded in and conditioned by social relations and cultural practice" (1998: 235).

This understanding of techniques within the framework of the social, as part of constructive cultures, is relevant in different dimensions in relation to architectural conservation. First, the techniques used in the production and reproduction of architectures that are conceptualised as heritage have been embedded in their own development and integrated in changing social contexts over time. In this way, these techniques and their various forms as well as the materials used and their meanings are marked by a dynamic constitution. In this sense, techniques and constructive cultures as a whole have been constantly immersed in processes of change, which implies a challenge to the very concept of conservation and to the principles of authenticity and integrity. Second, the techniques employed in contemporary conservation actions from both local communities and specialists are also embedded and conditioned by the social and cultural frameworks in which they are chosen and executed. In this context, the techniques employed in construction and conservation emerge within a field rife with disputes among different actors. The selection of a material or procedure within a wide range of available options is a social and political fact that implies taking a position in the face of reality.

Anthropology has historically inquired into the social and cultural reasons for various technological facts and the way in which different procedures establish and modify the material conditions of objects in relation to social subjects as a way to discuss technology as an objective field (Pfaffenberger 1988). In the first half of the 20th century, the French school of anthropology, starting with the work of Mauss and Leroi-Gourhan, concentrated particularly on techniques-no longer from a comparative perspective but rather as a way to understand how things come to be as they are through actions executed on the material based on the dynamism of the body and the objects used as tools. In this framework, techniques are relevant social productions (Lemonnier 1992) with the capacity to inform us about reality, as they are inseparable from it. Different technologies within a society may be related to each other and may, in turn, be related to other types of social phenomena, such that they are not constituted as independent spheres. Therefore, any type of action related to a change in technique implies, in one way or another, an impact on other dimensions of social reality.

The choice of one technique over another in the construction or conservation of architecture arises from a set of preferences within a certain limited universe of available options. Among these options, we select those we consider preferable on the basis of social representation
(Lemonnier 1992) and perceived possibilities, in both individual and collective terms. The construction of preferences for a certain way of doing something versus another, or for certain materials over others, emerges from collectively constructed consensuses that tend to guide the way we act without implying an obligation (Dietler and Herbich 1998). These consensuses are certainly not static but are subject to constant changes within the flows of life involving transformations in technical and material preferences and their social representations. In this framework, change is inherent to all social facts, including architecture and its associated techniques, and is not only the consequence of catastrophic, environmental or social events.

Change is part of these flows of life in which subjects and objects relate to each other and negotiate the new conditions of existence in relation to previous experiences and based on a flexibility that allows innovative responses to challenges. Indeed, in the framework of asymmetrical power relations between different social groups, people operate in complex modes, responding in unexpected ways to changing circumstances. Architectures are the result of the interactions of different constructive cultures over time, with processes of imposition, resistance, manipulation and appropriation regarding these impositions. Within these flows of life (Ingold 2002), the changing conditions of the subjects and their interrelations are in turn constituted in such a way that communities are dynamic realities that are modelled through articulation with other actors, such as state agencies, which are also not static entities and are permeated in different ways by social logics.

In a way, these changing realities carry a challenge for conservation actions, as they require the analysis of the different temporalities that intersect the multiplicity of meanings associated with the notion of change. To this end, ethnography, as an approach, a method and a text, helps us approach the conceptions of the different actors, including ourselves, involved in the becoming of architecture and its conservation. In a sense, ethnography implies a search for social realities in terms of the people who inhabit them rather than the application of external explanatory categories (Guber 2001). In any case, ethnography is an intersubjective process of knowledge construction between diverse actors (Clifford 1995) such that it does not simply imply an understanding of another reality but rather a reflection on one's own role as an observer embedded in a shared social dynamic.

Ethnographic approaches have not experienced particularly important development in the field of architectural conservation, although some interesting studies have been undertaken that took a critical look at the notion of 'authenticity' based on the observation of 
concrete conservation actions (Jones and Yarrows 2013; Yarrow 2018). While these works are relevant for a conceptual discussion on the field of conservation, for the purposes of this paper, ethnography is proposed as a methodology that aims to form a more complex understanding of the diversity of actors associated with any intervention regarding earthen architectural heritage, recognising a multiplicity of conceptions of its duration and change.

\section{Conservation and its challenges in northwestern Argentina}

Institutionalised earthen heritage in northwest Argentina relates to a significant group of buildings, mostly of colonial origin and built between the 16th and 18th centuries, that have been granted formal declarations of protection at the national or provincial level. The heritagisation of these buildings has its origins in the first systematic declarations that were issued on a national scale in connection with, in institutional terms, the creation of the current National Commission of Historical Monuments, Places and Properties (CNMLyBH by its Spanish name) in 1938 and, in social terms, the pursuit of a common past that would help build a national identity (Angelo 2010). In this context, the use of earthen techniques to build structures that have become National Historic Monuments (NHMs) was previously very prevalent (Herr and Rolón 2018) and continues to be so today in northwestern Argentina, where 69\% of NHMs are built with earthen techniques. The interesting thing about reviewing these processes in an attempt to complicate the social and technical meanings in today's heritage sector is that, on the one hand, in the process of creating a homogeneous national past from this architecture, these buildings were stripped of the complexity and heterogeneity of the constructive cultures of which they are part. Aesthetic aspects were privileged over the integrality of the properties. On the other hand, the development of these same processes in dialogue with the becoming of the communities has shaped ideas about the past and then about the present in regard to certain materialities and techniques that constitute complex common senses about the buildings' durability and quality and the conditions of their valuation, which today are in dispute in the framework used to vindicate the pluricultural projects that cross Latin America in a multi-scalar way (Angelo 2014).

In this way, the trajectory of conservation of these architectures implies not only involving ourselves in the complexity of these ideas but also within concrete relationships and actions between the different actors involved in the production and maintenance of heritage. First, we must consider that the declarations imply the direct intervention of public agencies on buildings and thus a set of tensions arising from the displacement of local communities as active agents in their conservation. Second, we must look at the complexities intrinsic to each of these actors in their trajectories. Local communities have sustained these buildings over time within the framework of complex social networks that are far from static and includes different 'transformative' actions that may ultimately be contrary to their 'authenticity', in the words of the Venice Charter (1964). However, at the same time, many of these actions have been functional, in many ways, to the hegemonic discourses on the need for transforming techniques in pursuit of durability.

Institutional spheres lack consensus and specific criteria, knowledge and regulations for interventions with earthen architecture. This is linked to prejudices about these techniques on the part of state and academic bodies, which have tended to preserve them by incorporating other materials. Although the actions and conservation criteria employed at different times by state agencies and academic-institutional bodies have varied, a primarily aesthetic discourse on heritage in relation to the complexity that the maintenance of certain earthen construction techniques require has overshadowed other discourses and led to the tendency to use concrete structural reinforcements. Furthermore, replacing mud plaster with cement has been the most widespread practice in the conservation of this heritage. In fact, this aesthetic view, which seeks to sustain heritage in an essential way, has coexisted with an ideology of modernisation (Angelo 2010) that justifies the replacement of certain materials considered 'backward' with 'new' technologies such as reinforced concrete. The decision to incorporate these technologies is not simply mediated by structural criteria.

Evidently, this is contrary to the criteria set out in the Nara Charter on understanding buildings in their own cultural and technical contexts of production. However, the question that emerges is then what has happened with these same production contexts over time. How do different local actors operate in this dialogue, although in asymmetrical roles, according to their different interests that are generally constituted in the face of these asymmetries?

The three cases that will be described expose the tensions between different criteria and actions leading to technical problems in the conservation of the properties through the diverse interactions between local and institutional actors.

\subsection{The Church of Uquía and the state's action}

The Church of Santa Cruz and San Francisco de Paula in the town of Uquía was built at the end of the 17th century as part of the reduction and evangelisation processes in the Quebrada de Humahuaca. Its structure reflects, with 

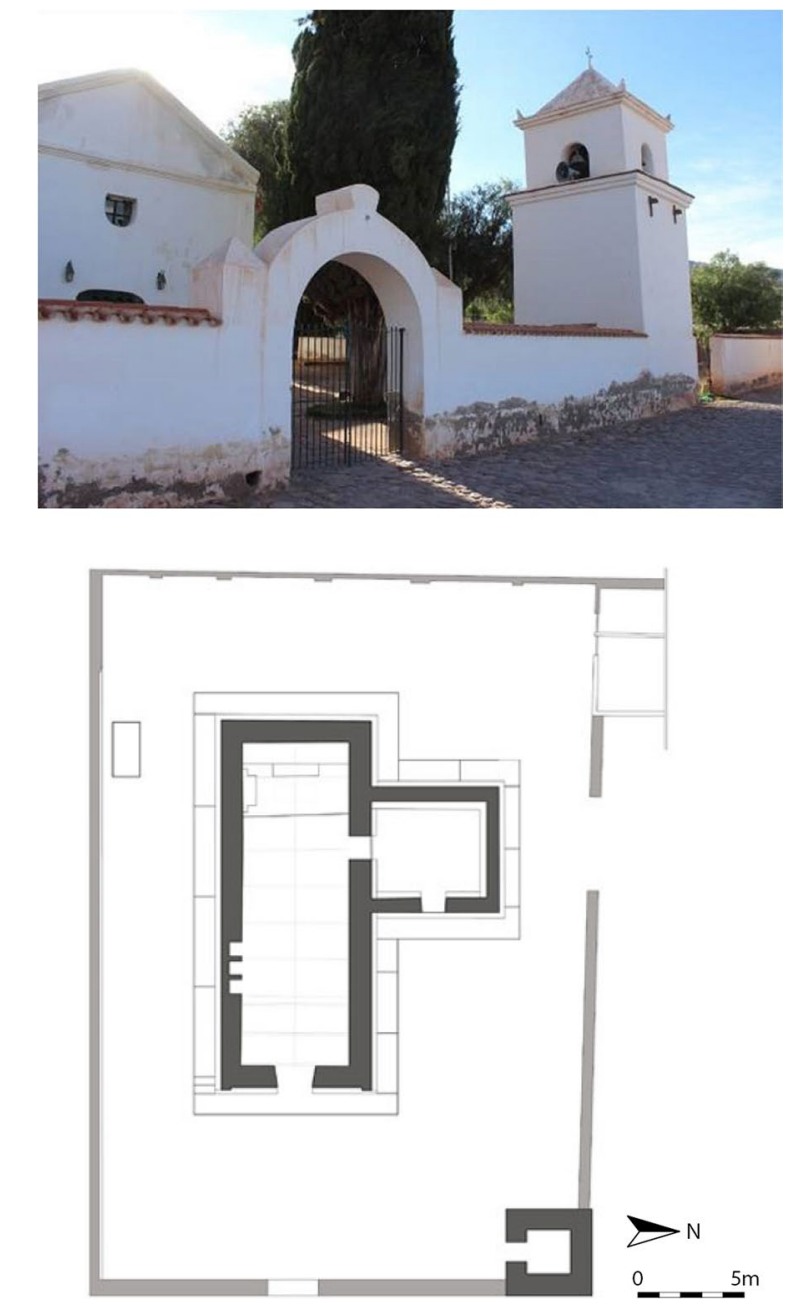

Fig. 2 Façade and ground plan of the Church of Uquía (Source: the authors)

variation, to the ecclesiastical typologies recognisable in the area (Gisbert and De Mesa 1997). Specifically, it has a single nave of $17 \mathrm{~m} \times 7 \mathrm{~m}$ from the outside and was built with stone and mud foundations and adobe walls formed with $60 \times 30 \times 10 \mathrm{~cm}$ blocks with a thickness of $1 \mathrm{~m}$. The nave has only one enclosure, which forms the sacristy on the north end (Fig. 2). Both the nave and the sacristy are gable-roofed with wooden A-frame trusses with a lower tensor. On the walls, the nave has a wooden collar beam that runs around the entire perimeter on which the tensors and trusses rest. The roof is finished with mud (torta de barro), a characteristic technique in the region that requires periodic maintenance. Finally, the chapel as a whole has an enclosed atrium and a separate tower, also made of adobe, on one of the corners.

In 1941, the Church of Uquía became one of the first buildings to be recognised by the Argentine state as an NHM as part of the early 20th-century search for a national architecture through the vindication of the country's pre-Hispanic and colonial past (Tomasi 2012). Simultaneously, the church has maintained a strong relationship with its community to the present day through religious practices and festivities. Nevertheless, in line with its heritagisation and commodification, there was a process of touristic valorisation, which also had an economic impact on the life of the community. In this context, the declaration of the church as an NHM was the starting point for a series of conservation interventions promoted by different state institutions, both national and provincial, which involved substantial transformations in the church's materiality and led to a series of pathologies of varying severity.

The need for a new intervention in 2019 arose from an analysis of the church's conservation trajectory as part of a collaborative project with the local community and researchers using historical and oral sources. At the time, the church had visible structural problems and was in a critical situation due to the presence of humidity in the nave as a consequence of previous interventions; this resulted in a debate between technicians and the community about the characteristics of the interventions. In this sense, it was a matter not only of reconstructing the church's conservation history, which had been patchily documented, but also of problematising the meanings of these interventions in relation to the interests converging at the property and of the need for its sustainability over time.

The analysis of historical photographs allows us to examine the first significant intervention at the time of the church's NHM declaration. This had an impact in both morphological and technical terms, as the top of the tower was modified, and a structure of reinforced concrete beams and columns was incorporated throughout the nave (Fig. 3). This intervention may have been motivated by structural damage present in the church, visible in four cracks in the longitudinal walls of the nave, which had been recorded in a 1912 inventory. The next recorded intervention was in 1986 and was initiated by the Ministry of Obras Públicas. This intervention was focused on the restoration of the roof, which involved changes in the mud covering and the replacement of the ceiling of wooden planks of cardon (Trichocereus atacamensis), a cactus characteristic of the region. It also involved the repair of plaster and, once again, reinforcements against cracks. $^{1}$

In 1989 , the 1986 project, which remained unfinished, was taken up again, this time considering the need to place structural reinforcement elements in the tower and modify the exterior structure of the chapel by putting a perimeter socket in place. This intervention was

${ }^{1}$ CNMyLH, Archive, Church of Uquía, 1986. 


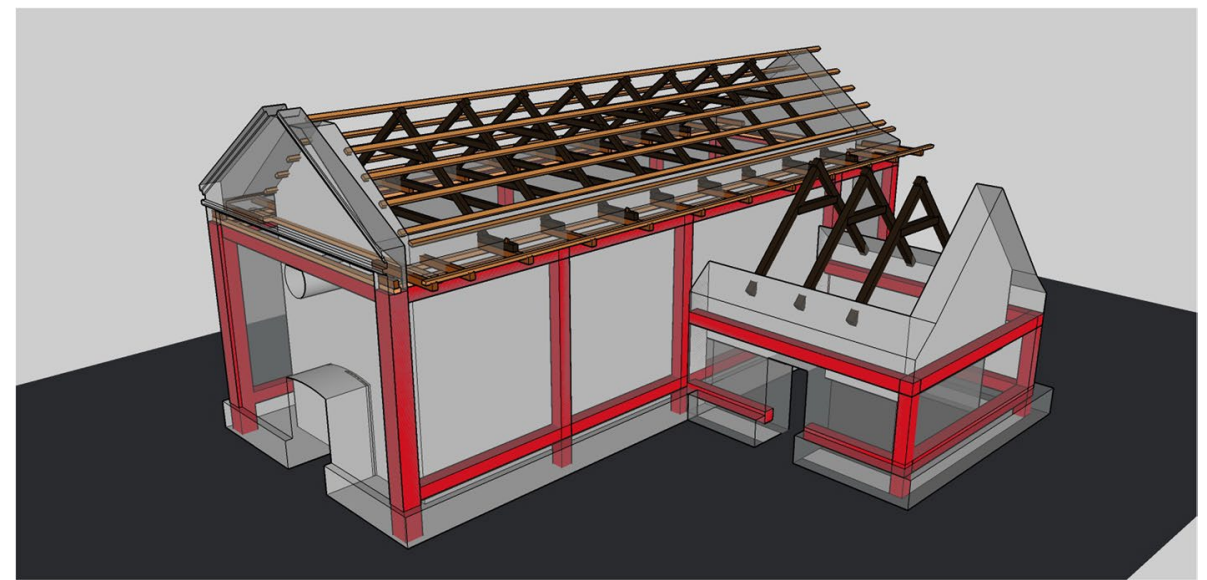

Fig. 3 Diagram of the reinforced concrete structure, shown in red, incorporated into the adobe walls at the beginning of the 20th century (Source: the authors)

the first in which a change in the materiality of the roof was registered; in this case, waterproof insulation was added between the layers of mud and a metallic element on the edge of the roof. Between 2012 and 2018, there were a new series of interventions, initially three, mainly motivated by the work of the General Direction of Architecture of the province of Jujuy. These interventions are particularly relevant, as a series of elements (concrete mortar, plastic fibre and liquid membrane) were added to the roof, altering its materiality and contributing to the generation of new pathologies, even though the intention was to improve the building's impermeability and durability. In this context, the interventions at the Church of Uquía are essentialist conservation efforts in aesthetic terms that coexist with a transformative vocation in technical terms, thus bridging romantic idealism and a civilising impulse (Krotz 1994).

The transformation of the materiality of the roof, the introduction of integral concrete structural reinforcement in the walls and the change in the top of the tower were solutions that not only did not improve the stability of the building but actually generated new pathologies. In the case of the roof, the integral transformation of its materiality led to a malfunctioning of the cover, with cracks in the upper layer allowing water to seep into the mud that was then unable to evaporate through exchange with the environment due to the presence of the cement and the upper membranes (Cornerstones Community 2006). Thus, the roof had serious humidity problems, allowing leaks into the interior of the church that damaged the adobe and wooden elements. As for the concrete structure, it is not connected to the adobe wall, and the section is insufficient to reinforce walls as thick as those of this particular church. Thus, the structure has not solved the problems observed in the form of the cracks and has actually increased the weakness of the structure in the case of a seismic event ${ }^{2}$ (Tomasi and Barada 2021). Likewise, the changes to the top of the tower involved not only the incorporation of foreign material into a structure that, due to its substantial weight on such a slender element as the tower, also increases the weakness of the general structure and also constitutes a complete change in the appearance of the church.

The different interventions that the church underwent were mainly prompted by the actions of various state agents in the interwoven relations between the fields of action of the numerous bodies dedicated to the valuation of heritage, such as the CNMLyBH, and those dedicated to the direct execution of intervention workboth of which exclude local communities. In technical terms, the choice of cement and concrete as intervention materials reveals a lack of specific knowledge on the part of state bodies about the properties of adobe, further fuelling the persistent discourse about the weakness of adobe, particularly in relation to seismic problems, that has been reinforced throughout the 20th century (Healey 2009). In fact, between the 1940s and 1950 s, concrete was widely used to reinforce numerous adobe constructions (Viñuales 2011), so the Church of Uquía is not an exceptional case. The incorporation of concrete into earthen constructions has been recorded in numerous countries involving adobe or cob buildings, such as those in Brazil, England and Mexico (Pecoraro 1993; Keefe et al. 2000; Guerrero Baca 2019). In New Mexico in the United States, it has been reported that cement began to be incorporated as a material for plaster in the 1930s (Cornerstones Community 2006),

\footnotetext{
${ }^{2}$ The seismicity of the area is moderate (2) according to INPRES (National Institute for Seismic Prevention).
} 
coinciding with the processes referred to above in the case of Argentina.

The most recent interventions on the roof reveal a perspective of the durability of buildings that is disruptive for earthen heritage in technical, and therefore social, terms. The change in the materiality of the mud roof was meant to increase its durability on the basis of other temporalities. The relationship between different actors and interests becomes even more complex here, as these same local temporalities associated with the various techniques have clashed with transformation processes that have redirected the interests of community ties, giving rise to several local voices also seeking the longer durability of the buildings as objects of consumption. It is at this point that we are confronted not only with damage to authenticity but also with a framework of broader and more dynamic cultural and social processes. The result is a rupture with the dynamics involved in maintaining the ties between the community and its heritage. In any case, in terms of the intention of state agents to improve the resistance and durability of the techniques, both operations were permeated by an objectual and aestheticist view in the pursuit of a static and objectual image, even when this meant altering the techniques and, therefore, social meanings of heritage.

\subsection{The flows of life in the Church of Tabladitas}

The Church of Nuestra Señora la Purísima in the town of Tabladitas is another highly valuable piece of ecclesiastical architecture in terms of religious devotions and the cohesion of the local community. However, unlike the church of Uquía, it has not been declared a NHM or otherwise formally recognised as such by provincial or national state organisms. Tabladitas is a small town of approximately 50 inhabitants about $10 \mathrm{~km}$ east of the city of Abra Pampa, one of the most significant cities in the highlands of Jujuy Province. It was probably built during the early Republican period in the 19th century, although the date cannot be easily determined due to a lack of historical documents. In this case, the proposed intervention for the church emerged from personal relationships and was not strictly institutional, as was the case in Uquía, even though the technical aspects in Tabladitas were mediated by institutional belonging. Regardless, the intervention process in Tabladitas lacked direct actions mediated by institutional interest in the property, and the community itself tried to take concrete actions to address the critical situation of the chapel. It is within this context that the dialogues and negotiations between different bodies of knowledge and ideas about the diagnosis and its remediation strategies articulated different temporalities involving history, immediate action and future sustainability.
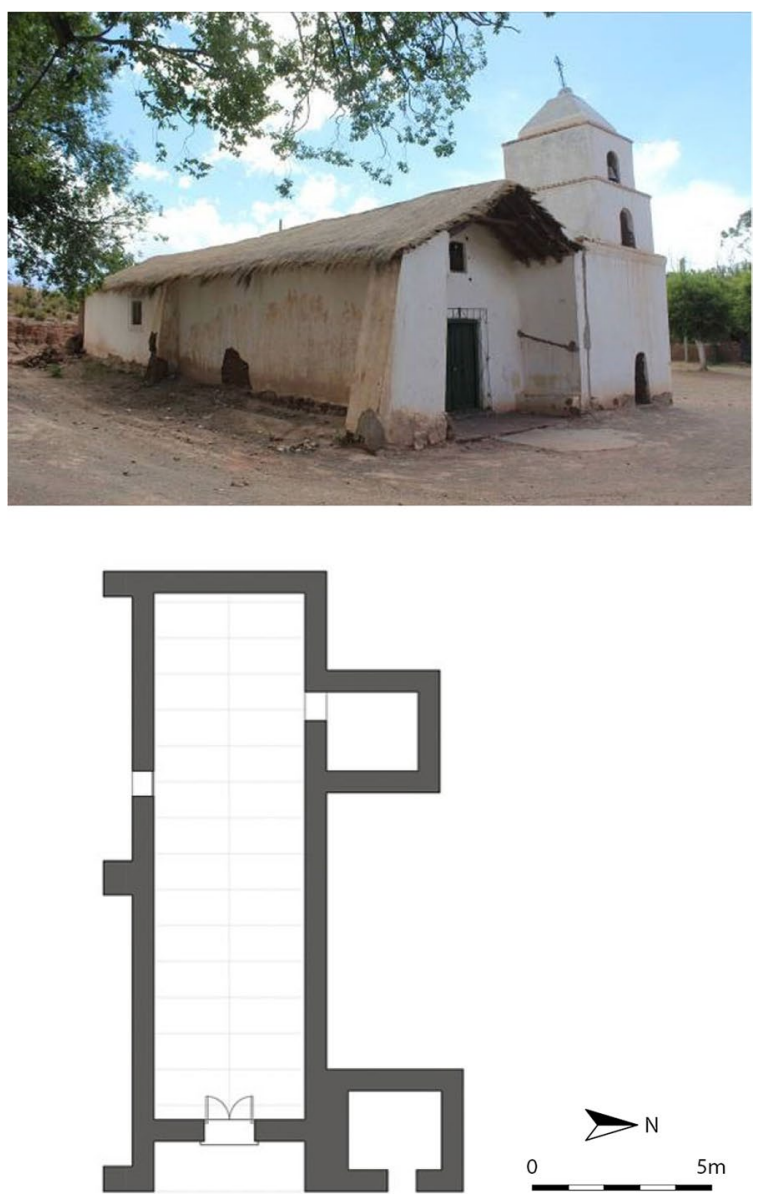

Fig. 4 View and ground plan of the Church of Tabladitas (Source: the authors)

Tabladitas is also a chapel with a single nave open to the east that is $17 \mathrm{~m}$ long and $7 \mathrm{~m}$ wide and has a small lateral enclosure, the sacristy, to the right (Gisbert and De Mesa 1997; Tomasi and Barada 2020). At the front, the church has an open chapel, a very characteristic element of chapels in the region, where the projection of the side walls and the roof generates a semicovered space linked to religious rituality (Fig. 4). Similar to the Church at Uquía, Tabladitas has a single tower, although in this case, it is attached to the nave and not to the perimeter wall of the atrium. In fact, at Tabladitas, the atrium is not closed, as it is in Uquía and other chapels in the region.

The tower has undergone its own transformation processes within the framework of the continuity of local practices linked to the chapel, at least during the 20th century. Images from the first half of the 20th century show that the tower was not previously completely attached to the side wall of the nave and was significantly taller and slenderer, with little differentiation between the two upper sections (Alameda 1935). Today, the tower is attached in line with the nave wall and has undergone 
morphological changes, including the replacement of the cupola with a pyramid at the top. These changes were carried out in the second half of the 20th century by the local community itself, in principle, without the direct action of external actors. It is relevant to consider, on the one hand, the persistence, even today, of community organisation around the building and its maintenance as strategies of social cohesion. However, it is also relevant to understand that even when there have been no direct actions of 'external' actors in the maintenance of the building, many of its transformations have been mediated by those same institutional discourses. Thus, it does not seem that the changes in the tower are associated, in terms of either materiality or morphology, with those observed in Uquía. Furthermore, it is also necessary to consider the implications that certain actions, such as exchanging the mud plaster on the exterior for cement plaster, have regarding the meanings associated with the apparent precariousness of mud and its durability.

This shows how these constructions are subject to transformations in the context of their insertion into temporalities that imply other notions of change as part of the flows in the relations between objects and subjects. Certainly, this modification of the tower could have arisen from previous structural problems and was, at the same time, the origin of new damage. As we have argued in this text, technical decisions are indivisible from their social meanings shaped over time.

The church in Tabladitas was also built with adobe masonry, with walls approximately $80 \mathrm{~cm}$ thick on foundations of mud-laid stone. The structure of the roof also reveals a system of A-frame trusses, without a lower tensor and boards of cardon wood tied with leather straps. On top of this structure, mesh, also made of leather, supports a continuous layer of straw that is finished with guayado (Fig. 5). This technique is characteristic of the region and consists of a series of superimposed horizontal strips of straw embedded in viscous mud, which provides excellent water and thermal insulation. Due to its specific characteristics, this technique requires the periodic renewal of the material to ensure its adequate performance. In different parts of the region, thatching has historically been a community conservation practice through which collective ties are established. In many cases, the institutionalisation of heritage has involved the action of other actors, such as construction companies. In the case of Tabladitas, however, the conservation of the thatch roof has remained a community practice, which is repeated periodically, within the framework of certain relationships the local people have with their architecture.

This renewal of the roof thatch is associated with a certain temporality of heritage, as it implies a conception of the durability of materials and a sense of authenticity based on their periodic renewal and change. In recent years, the failure of the trusses has caused an increase in horizontal stresses on the lateral walls, one of which was partially overturned and had a large horizontal crack at the base. In response, the community incorporated buttresses into the wall, but this only partially constrained the deformation. The degradation mechanism probably started with the leaks in the roof, which contributed to the deformation of the trusses as a result of delays in changing the thatch or the poor execution thereof. Changes in the temporalities of construction within the framework of new social dynamics have an impact on the conservation of buildings.

Even in this context, it is interesting to note, based on local documentary and oral sources, that the periodic rethatching has varied over time, particularly in terms of its organisational aspects, resources and timing. Of course, this temporality is also currently crossed by other dimensions of time in people's practices, which is more characteristic of capitalist labour logics. This implies that people's availability for these practices is not the same as in the past, so interventions are often delayed more than is advisable, and the tasks themselves are accelerated when they are finally executed, which has repercussions on the capacity and duration of the work.

It is also interesting to observe how the sustainability of this practice coexists with, for example, the placement of cement plaster, which allows us to problematize not only the heterogeneity of interests and agency among the community members themselves but also the way in which, in the negotiation with those institutional and institutionalised meanings, some aspects are radically transformed and others are maintained. The local population does not constitute itself as an external, isolated and independent entity but participates in different networks of relations that are crossed by institutionalisation. In this way, communities are inserted in these dynamics to which they respond in complex, novel and flexible ways within a framework of new ways of doing that are decoded in light of historically modelled practices.

\subsection{Technical intersections at Casa del Marques}

The case of Casa del Marqués, located in the town of Yavi, in the extreme north of Argentina, is unique, as it is a domestic building that was the head of the Marquisate of Tojo in colonial times (Sica 2016). The building dates from the first half of the 17th century, and since then, it has been the political, administrative and economic centre of an area that has been intensely disputed from colonial times until the mid-20th century. The local communities have played a leading role in this dispute, and the house itself, once the marquisate was dissolved, 
became a very valuable piece of heritage for the local community that was used for different purposes over time.

As we have mentioned, the house's morphology corresponds to that of other rural farms. It has a central courtyard and a square floor plan of $818 \mathrm{~m}^{2}$ of covered area on a single level made up of successive enclosures arranged around the courtyard (Fig. 6). Constructively, it has stone and mud foundations with adobe walls up to $1 \mathrm{~m}$ wide that were historically plastered with mud. The roof has A-frame trusses with a lower tensor, over which cane weaving was deployed and then finished with the mud roof technique, as in the Church of Uquía (Barada and Tomasi 2020).

This house forms an architectural ensemble with the Church of Yavi, which was declared an NHM in 1941, the same time as the Church of Uquía. However, the declaration of the house as an NHM was quite recent (only in 2001). At present, the house contains a provincial historical museum and a popular library supported with funds from the national government. Even though the house was declared an NHM relatively recently, the interventions by the state began several years earlier and have also led to substantial transformations in its materiality.

In fact, the first intervention, as part of the heritagisation of the house, took place during the 1950s and 1960s and, as with the intervention in Uquía, was not documented. This intervention addressed the walls and roofs, and a reinforced concrete beam was placed around the entire perimeter of the house (Fig. 7). As observed in the conservation actions initiated in 2018, this last element caused not only a significant alteration in the house's construction system but also damage to walls due to the shear stress of the beam on the adobe. As far as the roof is concerned, the original canes were replaced by
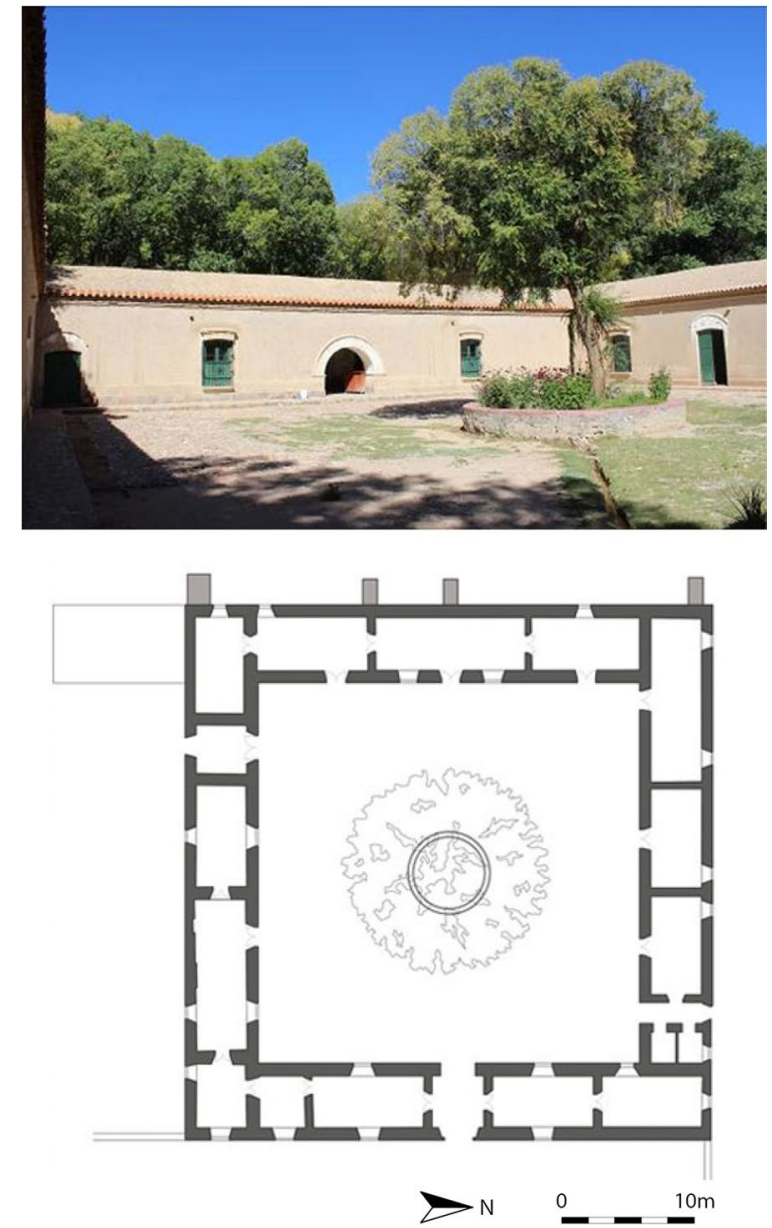

Fig. 6 View of the courtyard and general floor plan of Casa del Marqués (Source: the authors)

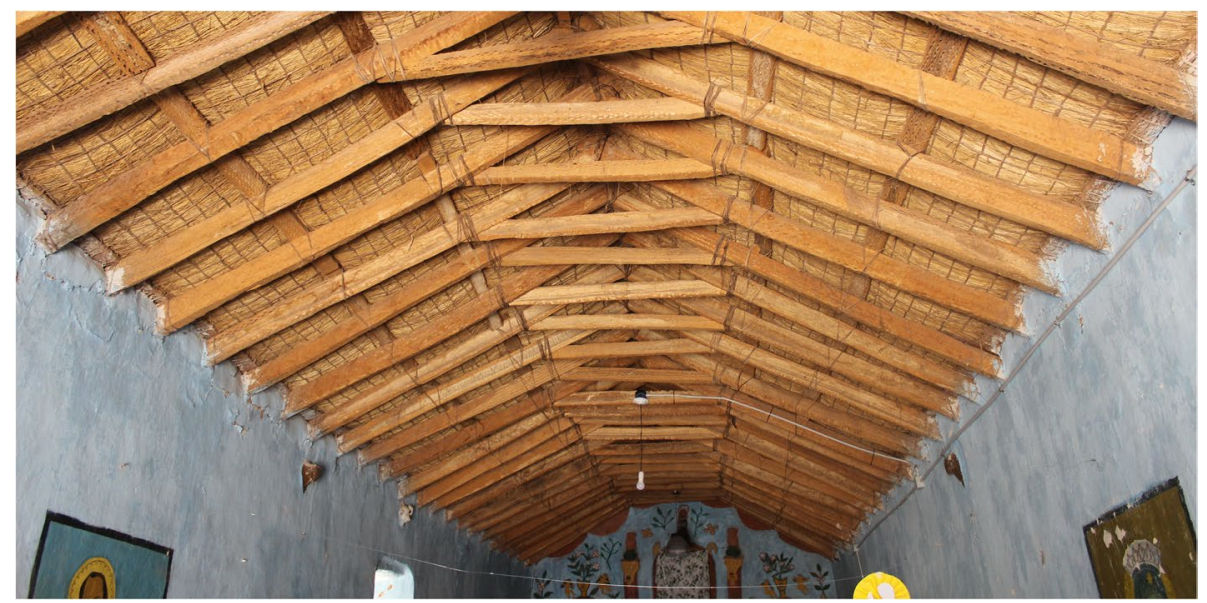

Fig. 5 Details of the cardon wood and thatch roof seen inside the nave (Source: the authors) 


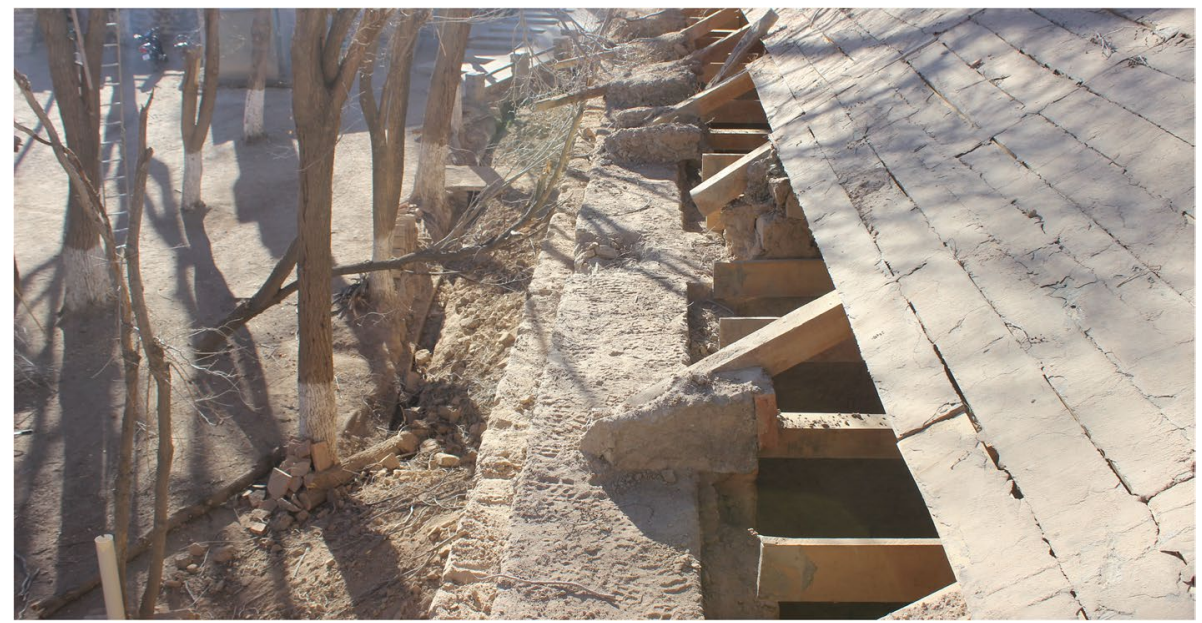

Fig. 7 Details of the reinforced concrete beam incorporated into the adobe walls (Source: the authors)

wooden boards, probably also associated with a reduction in the number of wooden trusses for each enclosure. These boards now show significant bending due to excess weight in the mud roof. As can be inferred, the poor execution of successive repairs led to a significant increase in the thickness of the roof.

In this framework, a striking issue found through the archival research in dialogue with the fieldwork with local communities (Barada and Tomasi 2020) is the existence of a postcard since 1971 featuring both the Casa del Marqués and the Church of Yavi, each of which has a red tile roof. While the church retains this feature at the present time, the roof of the house was reconverted to mud soon after. These tiles seen in the postcard reveals two relevant issues for the purposes of this article. The first is the attempt of state institutions to change the materiality of earthen architecture. Although we do not have precise knowledge of the conditions under which the operation took place, it is highly probable that it was carried out as part of the conservation work on the church, which is also a NHM. This change is therefore associated with the same meaning as in the case of Uquía insofar as the tiles constitute a "solution" to the problem of the roof's durability.

However, more relevant than these aspects is the social representations of roof tiles in terms of the construction of the 'colonial past', which leads us to the social condition of construction techniques and the mechanisms that guide such technological choices. In this sense, these roof tiles constituted a materiality that influenced the construction of the senses of the colonial buildings based on certain urban architectures. This implies a bias towards the complex realities of other areas, mostly rural, where earthen building techniques maintained an enormous presence in colonial buildings, even though they were part of profoundly asymmetrical power relations (Barada and Tomasi 2020). Far from considering these processes to be unidirectional, we must look with caution at the impact that these readings have had on local communities.

In this context, the preference for tiles as a solution for the roof of the Casa del Marqués was found among some locals through mentions of 'this way it will last forever' or 'it will be a true colonial house'. Similar expressions can be found in the valuation of the concrete reinforcements that were included in the adobe walls. These types of expressions allow us to analyse the impositions of state agents and local dynamics on complex heritage. The crossed trajectories of both actors bring us closer to understand the complex web of meanings involved.

\section{Conclusions}

The conservation of architectural heritage in general and of earthen buildings in particular is a social fact, as modelled in its logics of action within specific cultural frameworks. These frameworks, far from being homogeneous, are presented as a field in dispute, with tensions and conflicts, crossed by a multiplicity of diverse and changing conceptions from both local and institutional actors, as we have shown throughout this paper.

The conservation of earthen architecture is defined in the interaction of diverse actors within networks crossed by asymmetrical power relations. The formal recognition of the Church of Uquía as a heritage site at the beginning of the 20th century implied a redefinition of the conditions of its existence as it began to be defined, analysed and intervened in the logic of state agencies. This implied a modification of the relations between the object and the social subjects within the framework of the local community, thus 
establishing a new materiality (Miller 2005). In turn, the form of the buildings, in technical terms, also changed as other social representations were established. The same was observed in the case of Casa del Marqués in Yavi, although its declaration as an NHM came later, and even in the case of the Church of Tabladitas where in principle, there was no direct intervention by state agencies. In any case, the meanings of institutionality are broader than the actions strictly emanating from institutions.

Indeed, the techniques and materials used for the interventions, in local and institutional terms, are inseparable from an understanding of conservation as a social fact and are, therefore, proper for a field that is beyond a pretended objectivity. Rather, technological choices revealing a preference for one way of intervention or another are traversed by the relative subjectivities in the interaction of the different social actors, who in turn operate from their own representations. That is, certain procedures are selected within a limited universe of available options and modelled on the basis of social belonging. The incorporation of cement in the cases of the Church of Uquía and the Casa del Marques in Yavi emerged from a desire to reinforce the building following a conception of adobe as precarious and a conception of reinforced concrete as a universally suitable material. Thus, this was not an error in the intervention but rather the institutions' conception of the techniques.

One of the dimensions considered in this paper that requires an anthropological approach is associated with temporality, that is, with conceptions about the durability of architecture in a broad sense and of the specific materials involved. This necessarily led to a reflection on the changes in the materiality of objects considering the periodic replacement of certain materials, such as the thatched roof and the mud plaster in the Church of Tabladitas, and even more important morphological changes, such as the modification of the tower in the same church and the incorporation of buttresses into one of the side walls. Periodic interventions are inserted into the framework of certain relationships between subjects and objects concerning the construction of social ties, which are different but not completely isolated from those established in the framework of hegemonic institutionalities. In this sense, there is a need to recognise other possible temporalities in conservation work, along with other social representations of techniques, in order to challenge Western conceptions of what should remain unchanged. In any case, as we have tried to argue in this paper, technical decisions for intervention in heritage architecture emerge from the assembly of different ontologies, but this does not imply that these ontologies are constituted as antagonistic fields. Ethnography, as a conceptual approach and methodological practice in conservation allows us, specifically, to inhabit these disputed areas.

\section{Abbreviations}

CNMLyBH: National Commission of Historical Monuments, Places and Properties [Comisión Nacional de Monumentos, Lugares y Bienes Históricos]; NHM: National Historical Monument [Monumento Histórico Nacional].

\section{Acknowledgements}

The authors would like to thank all the communities involved in the research work carried out and the authorities of the Secretariat of Culture of the province of Jujuy, particularly the architect Valentina Millón.

\section{Authors' contributions}

All the information presented arises from the research done by the authors. All authors read and approved the final manuscript.

\section{Funding}

This research was carried out within the framework of a collaboration agreement between the National Scientific and Technical Research Council, Argentina (CONICET) and the Secretariat of Culture of the province of Jujuy.

Availability of data and materials

All the information presented arises from the research done by the authors.

\section{Declarations}

\section{Competing interests}

There are not competing interests.

Received: 19 April 2021 Accepted: 13 August 2021

Published online: 31 August 2021

\section{References}

Alameda, Julián. 1935. Argentina Católica [Argentina Catholic]. Buenos Aires: Benedictinos

Alonso González, Pablo. 2015. Patrimonio y Ontologías múltiples: hacia la coproducción del patrimonio cultural [Heritage and multiple ontologies: Towards the co-production of cultural heritage]. In Patrimonio y Multivocalidad Teoría, práctica y experiencias en torno a la construcción del conocimiento en Patrimonio [Heritage and multivocality theory, practice and experiences around the construction of knowledge in heritage], ed. Camila Gianotti García, David Barreiro Martínez, and Bianca Vienni Baptista, 179-198. Montevideo: Editorial Universitaria.

Angelo, Dante. 2010. The compulsive construction of heritage: Material culture and identity at the dawn of the 21st century in northwestern Argentina. PhD Thesis. Stanford: Stanford University.

Angelo, Dante. 2014. Abriendo el debate en torno a patrimonio en Chungara [Opening the heritage debate in Chungara]. Chungara, Revista de Antropología Chilena 46 (2): 173-176.

Barada, Julieta, and Jorge Tomasi. 2020. (Dis)continuidades constructivas en la restauración del patrimonio en tierra del noroeste argentino [Constructive (dis)continuities in the restoration of heritage on land in north-western Argentina]. Loggia. Arquitectura \& Restauración 33: 44-57.

Bluestone, Daniel. 2000. Challenges for heritage conservation and the role of research on values. In Values and heritage conservation research report, ed. Erica Avrami, Randall Mason, and Marta de la Torre, 65-67. Los Angeles: The Getty Conservation Institute.

Clifford, James. 1995. Dilemas de la cultura. Antropología, literatura y arte en la perspectiva posmoderna [Dilemmas of culture. Anthropology, literature and art in the postmodern perspective]. Barcelona: Editorial Gedisa.

Cornerstones Community. 2006. Adobe conservation. A preservation handbook. Santa Fe: Cornerstones Community.

Correia, Mariana. 2007. Teoría de la conservación y su aplicación al patrimonio en tierra [Conservation theory and its application to heritage on land]. Apuntes 20 (2): 202-219. 
Dietler, Michael, and Ingrid Herbich. 1998. Habitus, techniques, style: An integrated approach to the social understanding of material culture and boundaries. In The archaeology of social boundaries, ed. Miriam Stark, 334-356. Washington: Smithsonian.

Gisbert, Teresa, and José De Mesa. 1997. Arquitectura andina, 1530-1830 [Andean Architecture, 1530-1830]. La Paz: Embajada de España en Bolivia.

Guber, Rosana. 2001. La etnografía. Método, campo y reflexividad [Ethnography. Method, field and reflexivity]. Buenos Aires: Editorial Norma.

Guerrero Baca, Fernando. 2019. Comportamiento sísmico de viviendas tradicionales de adobe, situadas en las faldas del volcán Popocatépetl, México [Seismic behaviour of traditional adobe dwellings on the slopes of Popocatepetl volcano, Mexico]. Gremium 6 (11): 105-118.

Healey, Mark. 2009. The 'superstition of adobe' and the certainty of concrete. Shelter and power after the 1944 San Juan earthquake in Argentina. In Aftershocks: Earthquakes and popular politics in Latin America, ed. Jürgen Buchenau and Lyman L. Johnson, 100-128. Alburquerque: University of New Mexico Press.

Herr, Carola, and Guillermo Rolón. 2018. Registro documental e intervención patrimonial en la arquitectura religiosa de la provincia de Jujuy. Criterios implementados por la Comisión Nacional de Museos, de Monumentos y Lugares Históricos (CNMMyLH) durante el período 1938-1946 [Documentary record and patrimonial intervention in the religious architecture of the province of Jujuy. Criteria implemented by the National Commission of Museums, Monuments and Historic Places (CNMMyLH) during the period 1938-1946]. Anales del IAA 48 (1): 31-45.

Ingold, Tim. 2002. The perception of the environment essays on livelihood, dwelling and skill. London: Routledge.

Johnston, Chris, and David Myers. 2009. Resolving conflict and building consensus in heritage place management: Issues and challenges. In Consensus building, negotiation, and conflict resolution for heritage place management, ed. David Myers, Stacie Smith, and Gail Ostergren, 1-23. Getty Conservation Institute: Los Angeles.

Jones, Sian, and Thomas Yarrow. 2013. Crafting authenticity: An ethnography of conservation practice. Journal of Material Culture 18 (1): 3-26.

Keefe, Laurence, Linda Watson, and Richard Griffiths. 2000. Possible causes of structural failure in traditional cob buildings. In Terra 2000: 8th International conference on the study and conservation of earthen architecture, 254-260. London: James and James.

Krotz, Esteban. 1994. Alteridad y pregunta antropológica [Alterity and anthropological question]. Alteridades 4 (8): 5-11.

Lemonnier, Pierre. 1992. Elements for an anthropology of technology. Anthropological Papers 88: 1-24.

Miller, Daniel, ed. 2005. Materiality. Durham: Duke University Press.
Pecoraro, Ana Lucia. 1993. The conservation of the Church of Nossa Senhora do Rosario, Embu, São Paulo Brazil. In Terra 93: 7 a Conferência Internacional sobre o Estudo e Conservação da Arquitectura de Terra, 278-281. Lisbon: Direcção Geral dos Edifícios e Monumentos Nacionais.

Pfaffenberger, Bryan. 1988. Fetishised objects and humanised nature: Towards an anthropology of technology. Man, New Series 23 (2): 236-252.

Sica, Gabriela. 2016. Procesos comunes y trayectorias diferentes en torno a las tierras de los pueblos de indios de Jujuy. Siglo XVI al XIX [Common processes and different trajectories around the lands of the Indian villages of Jujuy. 16th to 19th century]. Revista del Museo de Antropología 9 (2): 171-186.

Smith, Laurajane. 2011. El "'espejo patrimonial'. ¿llusión narcisista o reflexiones múltiples?" [The "Patrimonial Mirror". Narcissistic delusion or multiple reflections?]. Antípoda. Revista De Antropología y Arqueología 12: 39-63.

Tomasi, Jorge. 2012. Mirando lo vernáculo. Tradiciones disciplinares en el estudio de 'otras arquitecturas' en la Argentina del siglo XX [Looking at the vernacular. Disciplinary traditions in the study of "other architectures" in 20th century Argentina]. Revista Área 17: 68-83.

Tomasi, Jorge, and Julieta Barada. 2020. Patrimonios coloniales y republicanos. Caracterización de sus técnicas y materialidades en la provincia de Jujuy (Argentina) [Colonial and Republican heritage. Characterisation of their techniques and materialities in the province of Jujuy (Argentina)]. Revista Gremium 7 (14): 53-68.

Tomasi, Jorge, and Julieta Barada. 2021. Alterations and pathologies in earthen heritage. The introduction of cementitious materials in case studies in the north of Argentina. In XVII CINPAR, international conference on pathology and constructions rehabilitations. In press.

Viñuales, Graciela. 2011. Monumentos Nacionales de adobe y otras técnicas de tierra [National monuments of adobe and other earthen techniques]. Boletín Informativo de la Comisión Nacional de Monumentos 2011: 21-29.

Watkins, Joe. 2019. From the inside looking out: Indigenous perspectives on heritage values. In Values in heritage management. Emerging approaches and research directions, ed. Erica Avrami, Susan Macdonald, Randall Mason, and David Myers, 210-222. The Getty Conservation Institute: Los Angeles.

Yarrow, Thomas. 2018. How conservation matters: Ethnographic explorations of historic building renovation. Journal of Material Culture 24 (1): 3-21.

\section{Publisher's Note}

Springer Nature remains neutral with regard to jurisdictional claims in published maps and institutional affiliations.

\section{Submit your manuscript to a SpringerOpen ${ }^{\circ}$ journal and benefit from:}

- Convenient online submission

- Rigorous peer review

- Open access: articles freely available online

- High visibility within the field

- Retaining the copyright to your article

Submit your next manuscript at $\boldsymbol{\Delta}$ springeropen.com 